\title{
ATM participates in the regulation of viability and cell cycle via ellipticine in bladder cancer
}

\author{
SHUIXIANG TAO ${ }^{1,2}$, SHUAI MENG ${ }^{1}$, XIANGYI ZHENG ${ }^{1}$ and LIPING XIE ${ }^{1}$ \\ ${ }^{1}$ Department of Urology, The First Affiliated Hospital, School of Medicine, Zhejiang University, Hangzhou, \\ Zhejiang 310003; ${ }^{2}$ Department of Urology, Shaoxing People's Hospital, Shaoxing, Zhejiang 312000, P.R. China
}

Received December 9, 2015; Accepted December 8, 2016

DOI: $10.3892 / \mathrm{mmr} .2017 .6141$

\begin{abstract}
Ellipticine, an alkaloid isolated from Apocyanaceae plants, has been demonstrated to exhibit antitumor activity in several cancers. However, the effect and the mechanisms underlying its action have not been investigated in human bladder cancer cells. The aim of the present study was to investigate the effect and mechanism of ellipticine on the behavior of T-24 bladder cancer cells. T-24 cells were treated with varying concentrations and durations of ellipticine. Cell viability was evaluated by Cell Counting Kit- 8 assay. Cell motility was analyzed by Transwell migration assay. Flow cytometry, reverse transcription-quantitative polymerase chain reaction and western blot analyses were performed to detect the cell cycle and signaling pathways involved. The results demonstrated that ellipticine suppressed proliferation and inhibited the migration ability of T-24 bladder cancer cells in a dose- and time-dependent manner, and resulted in $\mathrm{G} 2 / \mathrm{M}$ cell cycle arrest. The mechanism of this action was demonstrated to be due to ellipticine-triggered activation of the ATM serine/threonine kinase pathway. These data therefore suggest that ellipticine may be effective towards treating human bladder cancer.
\end{abstract}

\section{Introduction}

Ellipticine [5,11-dimethyl-6H-pyrido(4,3-b)carbazole] is a naturally occurring alkaloid isolated from the leaves of Apocyanaceae plants (1). Ellipticine and its analogues have demonstrated potent anti-cancer activity in a phase II study of advanced breast cancer (2) and several other types of cancer (3). The main reason why ellipticine and its derivatives have become noteworthy is its high efficiency against cancer, its rather limited toxic side effects, and its limited intrinsic

Correspondence to: Professor Liping Xie, Department of Urology, The First Affiliated Hospital, School of Medicine, Zhejiang University, 79 Qing Chun Road, Hangzhou, Zhejiang 310003, P.R. China

E-mail: xielp@zjuem.zju.edu.cn

Key words: ellipticine, bladder cancer, viability, cell cycle, ATM toxicity (4). The chemopreventive activity of ellipticine is likely to be associated with its ability to modulate pathways involved in cell cycle progression (5) and apoptotic cell death (6-8). However, its efficacy in bladder cancer cells and the associated mechanisms of action are not completely understood.

Bladder cancer is the fourth commonest male malignancy and is associated with significant morbidity and mortality (9). Approximately $90 \%$ of all bladder cancer cases are classified as urothelial cell carcinomas (UCC) which are originated from epithelial cells lining the interior of the urothelial organ (10). Therapeutic options for bladder cancer include surgical resection, intravascular chemotherapy, radiation, immunotherapy and system chemotherapy. Despite the low-grade cases (good differentiation) having an excellent prognosis, high-grade cases (medium and poor differentiation) progress to invasion, metastases and death (11). Therefore, identifying novel and alternative therapeutic strategies is critical for prolonging survival.

On the basis of its effectiveness in other types of cancer, ellipticine could be a potential candidate for the therapy of bladder cancer. The present study investigated whether ellipticine reduces the proliferation and migration abilities of bladder cancer cells and its underlying molecular mechanisms.

\section{Materials and methods}

Reagents and cell culture. Ellipticine ( $\geq 99 \%$ pure; Sigma-Aldrich; Merck Millipore, Darmstadt, Germany) was dissolved in dimethylsulfoxide (DMSO) to make $10 \mathrm{mM}$ stock solutions and was stored at $-20^{\circ} \mathrm{C}$. Primary antibodies against phosphorylated (p-)ATM (cat. no. 5883; 1:1,000), M-phase inducer phosphatase 3 (Cdc25) (cat. no. 4688, 1:1,000), p-Cdc25C (Ser-216) (cat. no. 4901; 1:1,000), checkpoint kinase 1 (Chk1) (cat. no. 2360; 1:1,000), p-Chk1 (Ser-345) (cat. no. 2348, 1:1,000), Cyclin B1 (cat. no. 12231, 1:1,000), cyclin dependent kinase 1 (Cdk1) (cat. no. 7519; 1:1,000), and secondary antibodies (cat. no. 7074; 1:5,000) were purchased from Cell Signaling Technology (Danvers, MA, USA). The bicinchoninic acid protein assay kit was purchased from Pierce; Thermo Fisher Scientific, Inc. (Waltham, MA, USA). The human bladder cancer cell line T-24, obtained from the Shanghai Institute of Cell Biology, Chinese Academy of Sciences (Shanghai, China), was cultured in RPMI-1640 medium (HyClone; GE Healthcare, Logan, 
UT, USA) supplemented with $10 \%$ fetal bovine serum (FBS; Sigma-Aldrich; Merck Millipore), $100 \mathrm{U} / \mathrm{ml}$ penicillin and $100 \mathrm{mg} / \mathrm{ml}$ streptomycin, and was grown in an incubator with $5 \% \mathrm{CO}_{2}$ at $37^{\circ} \mathrm{C}$.

Cell viability assay. The effect of ellipticine on the viability of T-24 cells was evaluated by Cell Counting Kit-8 (CCK-8) assay. Approximately $10 \times 10^{4} \mathrm{~T}-24$ cells were seeded in 96-well plates. Following an overnight incubation, T-24 cells were treated with either $1 \mu \mathrm{l} / \mathrm{ml}$ DMSO (vehicle control) or 1 , $2,4,8$ or $16 \mu \mathrm{M}$ ellipticine for $24 \mathrm{~h}$. Following incubation, $10 \%$ CCK-8, diluted in normal culture medium, was added to each well and incubated at $37^{\circ} \mathrm{C}$ until color conversion occurred. Absorbance at $450 \mathrm{~nm}$ was then measured using a MRX II absorbance reader (Dynex Technologies, Chantilly, VA, USA). Results were displayed as a percentage of growth, with $100 \%$ representing control cells treated with DMSO alone.

RNA isolation and reverse transcription-quantitative polymerase chain reaction ( $R T-q P C R)$. Total RNA was extracted from T-24 cells treated with 2,4 or $8 \mu \mathrm{M}$ ellipticine or $1 \mu \mathrm{l} / \mathrm{ml}$ DMSO using RNAiso Plus (Takara Biotechnology Co, Ltd., Dalian, China) and transcribed into cDNA using the PrimeScript RT Reagent Kit (Takara Biotechnology Co, Ltd.). qPCR was performed using an ABI 7500 FAST Real-Time PCR System (Applied Biosystems; Thermo Fisher Scientific, Inc.) and a SYBR-Green PCR kit (Takara Biotechnology Co, Ltd.). The relative expression level of mRNA was quantified with the $2^{-\Delta \Delta \mathrm{Cq}}$ method (12) following normalization with the endogenous reference, GAPDH. The primers used were as follows: ATM, forward 5'-TTACGGGTGTTGAAGGTG TCT-3' and reverse 5'-GGATTCATGGTCCAGTCAAAG-3'; and GAPDH, forward 5'-GCTGAACGGGAAGCTCACTG-3' and reverse 5'-GTGCTCAGTGTAGCCCAGGA-3'.

In vitro motility assays. T-24 cells were seeded in a 6-well plate at a density of $8 \times 10^{4}$ cells/well. Following overnight incubation, cells were treated with $0.2,0.4$ or $0.8 \mu \mathrm{M}$ ellipticine for $24 \mathrm{~h}$, then harvested by centrifugation at $800 \mathrm{x} g$ for $5 \mathrm{~min}$ at $20^{\circ} \mathrm{C}$. Cells were resuspended in growth medium at a concentration of $4 \times 10^{5}$ cells $/ \mathrm{ml}$, and $0.2 \mathrm{ml}$ of each was added to the top chamber of each well (24-well insert, $8 \mu \mathrm{m}$ pore size; Merck Millipore), and growth medium containing 20\% FBS was added to the lower chamber of each well to act as a chemoattractant. The cells were allowed to migrate to the lower chamber for $24 \mathrm{~h}$ in an incubator at $37^{\circ} \mathrm{C}$ and those that did not invade through the membrane were removed with a cotton swab by scraping the upper surface of the membrane. Cells that had migrated to the lower surface of the membrane were fixed for 15 min in $100 \%$ methanol and stained with $0.1 \%$ crystal violet for observation and counting. Experiments were performed in triplicate.

Cell cycle assay. Cells were seeded in 6-well culture dishes at concentrations determined to output $60-70 \%$ confluence within $24 \mathrm{~h}$, and then treated with $1,2,4,8$, or $16 \mu \mathrm{M}$ ellipticine. Following $24 \mathrm{~h}$ incubation, cells were washed with PBS and fixed using pre-cooled $70 \%$ ethanol at $4^{\circ} \mathrm{C}$ overnight. The cells were washed and subjected to propidium iodide (PI)/RNase staining for $30 \mathrm{~min}$ at $37^{\circ} \mathrm{C}$ in the dark. Cell cycle distribution was then analyzed using the FC500 flow cytometer (Beckman Coulter Inc., Brea, CA, USA) and BD FACSDiva software (version 6.1.3, BD Biosciences, Franklin Lakes, NJ, USA).

Western blot analysis. Cells were harvested at $24 \mathrm{~h}$ following ellipticine treatment, washed with PBS, and lysed with lysis buffer at $4^{\circ} \mathrm{C}$ for $45 \mathrm{~min}$ [10 mmol/l Tris- $\mathrm{HCl}, 0.25 \mathrm{~mol} / \mathrm{l}$ sucrose, $5 \mathrm{mmol} / 1$ EDTA, $50 \mathrm{mmol} / 1 \mathrm{NaCl}, 30 \mathrm{mmol} / \mathrm{l}$ sodium pyrophosphate, $50 \mathrm{mmol} / \mathrm{l} \mathrm{NaF}, 1 \mathrm{mmol} / 1 \mathrm{Na}_{3} \mathrm{VO}_{4}$, $1 \mathrm{mmol} / 1$ phenylmethylsulfonyl fluoride, and $2 \%$ cocktail (protease inhibitor, pH 7.5; Servicebio, Wuhan, China) and then centrifuged at $1,200 \times \mathrm{g}$, for $15 \mathrm{~min}$ at $4^{\circ} \mathrm{C}$. The protein concentrations were measured by bicinchoninic acid assay and equalized to $4 \mu \mathrm{g} / \mu \mathrm{l}$ using lysis buffer. Each sample was supplemented with $4 \mathrm{X}$ loading buffer and boiled for $5 \mathrm{~min}$. Appropriate amounts of protein (20-30 $\mu \mathrm{g}$ ) were resolved by electrophoresis in 10-12\% Tris-glycine polyacrylamide gels and transferred onto nitrocellulose membranes. Membranes were blocked with 5\% nonfat milk in Tris-buffered saline solution (TBS) containing $0.05 \%$ Tween [TBST; $10 \mathrm{mM}$ Tris- $\mathrm{Cl}$ (pH 7.4), $150 \mathrm{mM} \mathrm{NaCl}, 0.1 \%$-20], then hybridized overnight at $4^{\circ} \mathrm{C}$ with the appropriate primary antibody. They were then washed with TBST and incubated with horseradish peroxidase-conjugated secondary antibody at 1:1,000 dilution in TBST by gentle agitation at room temperature for $2 \mathrm{~h}$, and subsequently washed. The signal density was visualized using an enhanced chemiluminescence system (Pierce; Thermo Fisher Scientific, Inc.). The results were quantitated using ImageJ version 1.48 (National Institutes of Health, Bethesda, MD, USA).

Statistical analysis. The data analyzed were from three independent experiments. Statistical significance was assessed between various treatment groups and controls using analysis of variance (ANOVA). Least-Significant Difference (LSD) was used to compare individual groups following ANOVA. $\mathrm{P}<0.05$ was considered to indicate a statistically significant difference.

\section{Results}

Ellipticine affects cell growth in T-24 cells. The CCK-8 assay revealed that compared to untreated and DMSO controls, ellipticine treatment induced a dose- and time-dependent inhibition of T-24 cell growth (Fig. 1). There was no significant difference between untreated control and DMSO control, which indicated that the vehicle, DMSO, did not affect the proliferation ability of T-24 cells (Fig. 1). Compared to untreated cells, ellipticine treatment resulted in a significant reduction in cell viability with increasing concentration and time, particularly at the concentration of 8 and $16 \mu \mathrm{M}$ (Fig. 1). The $50 \%$ growth inhibitory concentration $\left(\mathrm{IC}_{50}\right)$ for ellipticine treatment was estimated to be $4.3,3.8$, and $2.0 \mu \mathrm{M}$ for 24,48 , and $72 \mathrm{~h}$, respectively (Fig. 1). These results, therefore, demonstrate that ellipticine has a significant inhibitory effect on T-24 cell proliferation.

Ellipticine inhibits T-24 cell migration. As demonstrated in Fig. 1, when $1 \mu \mathrm{M}$ ellipticine was added for $24 \mathrm{~h}$, the viability of the cells was not significantly altered. Hence, the concentrations of $0.2-0.8 \mu \mathrm{M}$ and the time of $24 \mathrm{~h}$ were selected to 


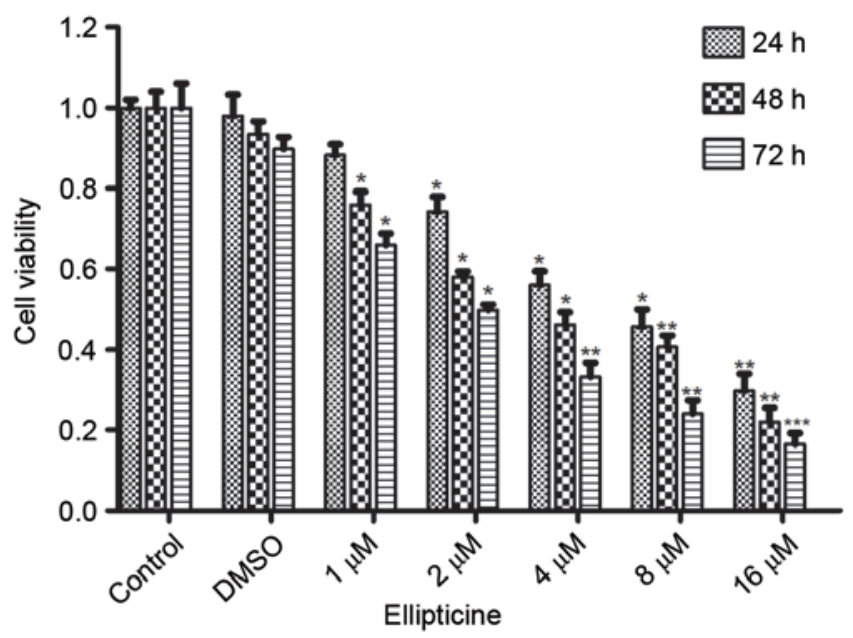

Figure 1. Cytotoxicity effects of ellipticine in T-24 bladder cancer cells. Cell proliferation and viability were determined by a Cell Counting Kit- 8 assay in untreated (control) cells or cells treated with either DMSO vehicle control (DMSO) or various concentrations of ellipticine (1-16 $\mu \mathrm{M})$. The data are presented as the mean \pm standard deviation. ${ }^{*} \mathrm{P}<0.05,{ }^{* *} \mathrm{P}<0.01,{ }^{* * * *} \mathrm{P}<0.001$ vs. untreated control. DMSO, dimethylsulfoxide.

perform the migration assay and examine the effect of ellipticine on the migration ability of T-24 cells. As demonstrated in Fig. 2, treatment with 0.4 and $0.8 \mu \mathrm{M}$ ellipticine resulted in a significant reduction in motility compared with untreated control ( $\mathrm{P}<0.05$ and $\mathrm{P}<0.01$, respectively; Fig. 2).

Ellipticine induces G2/M phase cell cycle arrest. To test the hypothesis that an arrest of cells at a specific cell cycle check point may be involved, the effect of ellipticine on cell cycle perturbations was assessed. Compared with the untreated controls, ellipticine treatment induced a significant arrest of T-24 cells in the G2/M phase of the cell cycle. Cell cycle analysis suggested that the percentage of $\mathrm{G} 2 / \mathrm{M}$ phase-arrested cells in the control was $13.75 \%$, while the percentage of $\mathrm{G} 2 / \mathrm{M}$ phase-arrested cells increased significantly following $24 \mathrm{~h}$ treatment with 8 and $16 \mu \mathrm{M}$ ellipticine compared with the untreated control (20.25 and $23.75 \%$, respectively; $\mathrm{P}<0.05$ and $\mathrm{P}<0.05$ respectively; Fig. 3A). Concomitant with the increased G2/M phase cell population, ellipticine treatment resulted in a reduction in cell numbers arrested in the G1 phase of the cell cycle compared with the untreated control (Fig. 3B).

Ellipticine modulates ATM-Chkl-Cdc25C-Cdk1 pathway. To explore the molecular events leading to ellipticine mediated G2/M phase cell cycle arrest, the signaling cascade responsible for $\mathrm{G} 2 / \mathrm{M}$ checkpoint control was examined further. As cellular responses to DNA damage during cell cycle are coordinated primarily by activated ATM kinase and its following signaling cascades, mRNA expression levels of ATM in T-24 cells treated with different concentrations of ellipticine were tested. As demonstrated in Fig. 4A, the expression of ATM mRNA was significantly upregulated following treatment with 2,4 and $8 \mu \mathrm{M}$ ellipticine compared with control $(\mathrm{P}<0.05, \mathrm{P}<0.05$ and $\mathrm{P}<0.01$, respectively). Next, the effect of ellipticine on protein expression of p-ATM, Chk1 and p-Chk1 (Ser345) were examined. Compared with control, p-ATM and p-Chk1 protein levels were significantly increased, while Chk1 total protein
A

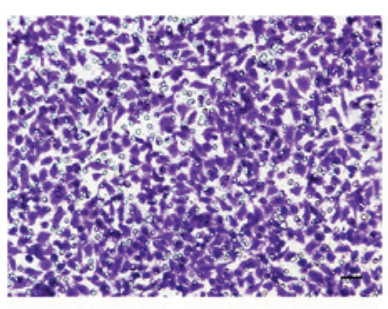

Control

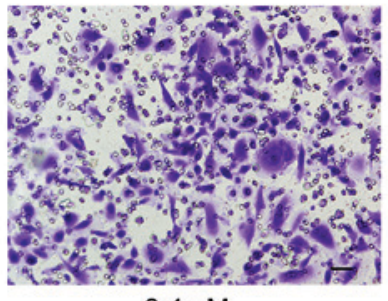

$0.4 \mu \mathrm{M}$

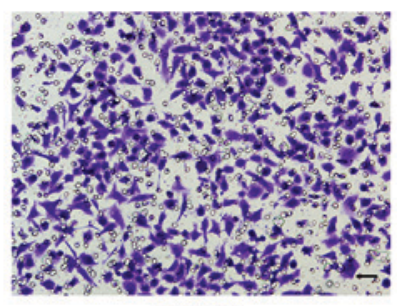

$0.2 \mu \mathrm{M}$

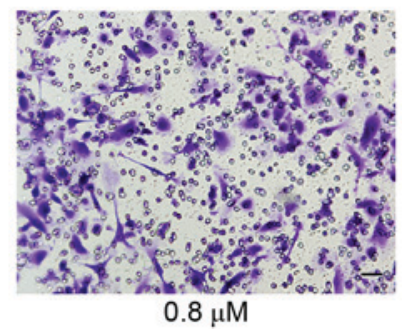

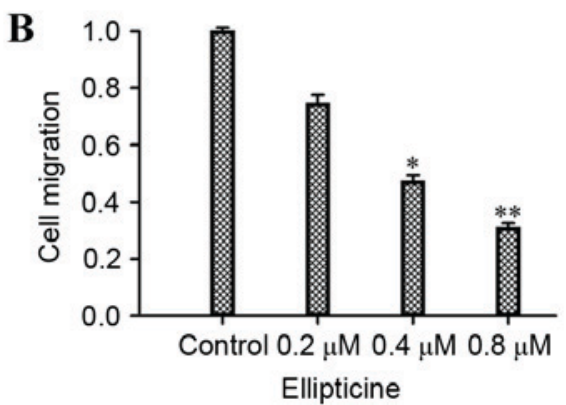

Figure 2. Effect of ellipticine on T-24 cell migration. Cells treated with $0-0.8 \mu \mathrm{M}$ ellipticine were allowed to migrate through uncoated Transwell membranes for $24 \mathrm{~h}$, then were fixed, stained, and counted. (A) Representative images of ellipticine treated/untreated migrated cells on the bottom of the Transwells. Scale bars, $100 \mu \mathrm{m}$. (B) Quantification of cell migration analysis from three independent experiments. The data are presented as mean \pm standard deviation. ${ }^{*} \mathrm{P}<0.05,{ }^{* *} \mathrm{P}<0.01$ vs. untreated control.

was reduced, following $24 \mathrm{~h}$ treatment with 2,4 , and $8 \mu \mathrm{M}$ ellipticine (Fig. 4B). Chk1 activation has been demonstrated to phosphorylate Cdc25C on Ser-216 in vitro (13). The effect of ellipticine on total Cdc25C and p-Cdc25C (Ser-216) was, therefore, further examined. Following ellipticine treatment, total $\mathrm{Cdc} 25 \mathrm{C}$ protein significantly decreased while $\mathrm{p}-\mathrm{Cdc} 25 \mathrm{C}$ was upregulated (Fig. 4B), which suggests that activation of Chk1 by ellipticine may be due to the inactivation of Cdc25C. Downstream components of Cdc25C, Cdk1 and Cyclin B1, were also down- and upregulated, respectively (Fig. 4B). These results suggest that the ATM-Chk1-Cdc25C-Cdk1 cascade is involved in the G2/M arrest of bladder cancer cells via checkpoint activation following ellipticine treatment.

\section{Discussion}

The present study revealed that ellipticine, a naturally occurring alkaloid, exhibits an inhibitory function on T-24 bladder cancer cell proliferation and migration. The chemopreventive/therapeutic potential of ellipticine against bladder cancer was demonstrated to be mediated by induction of cell cycle arrest and inhibition of migration. The antiproliferative effect of ellipticine on cancer cells has been previously reported (3). Based on its action on other reported cancer types, the present 

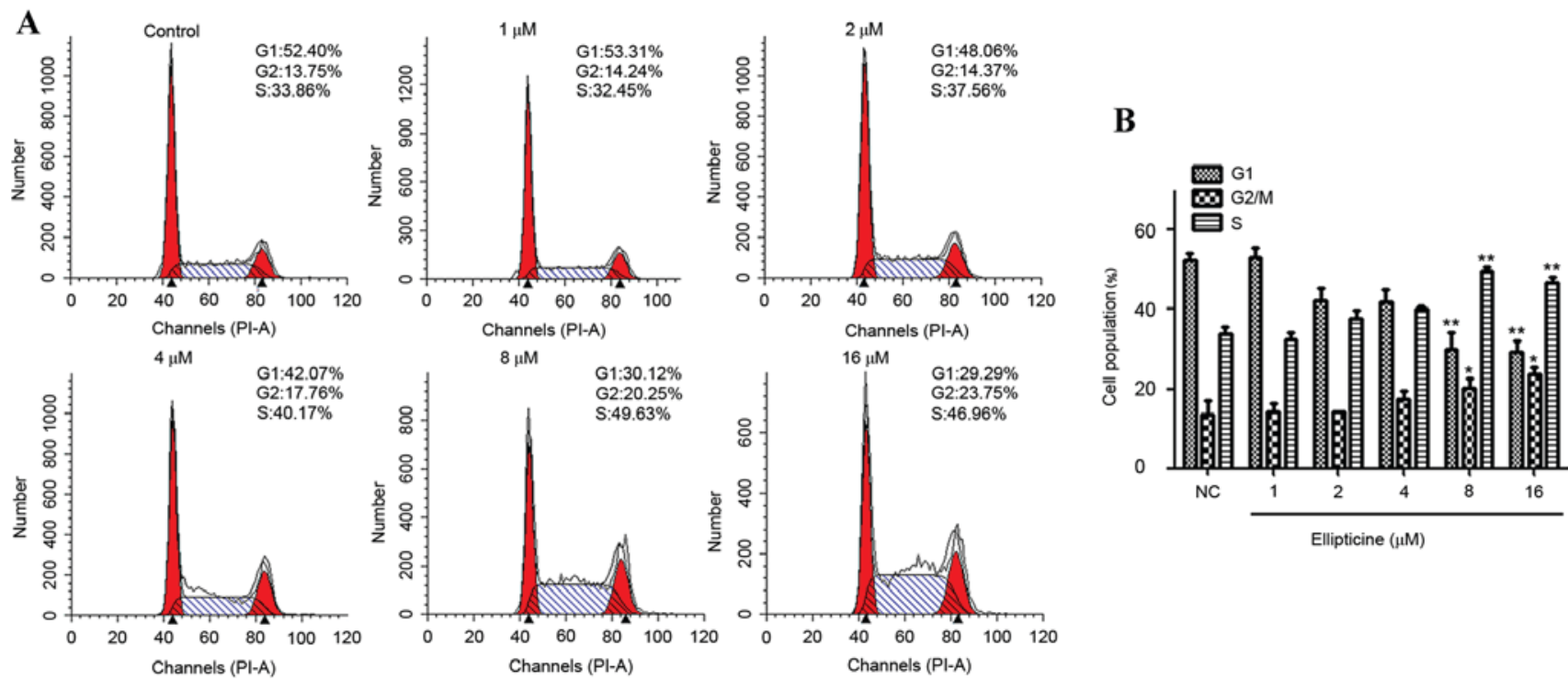

Figure 3. Cell cycle analysis of T-24 bladder cancer cells treated with ellipticine. (A) Cells were treated with different concentrations of ellipticine for $24 \mathrm{~h}$ and then stained with propidium iodide. The DNA content was analyzed by flow cytometry. G1, S and G2/M indicate the respective cell cycle phase. (B) Quantification of cell cycle analysis from three independent experiments. The data are presented as mean \pm standard deviation. ${ }^{*} \mathrm{P}<0.05$, ${ }^{* * *} \mathrm{P}<0.01 \mathrm{vs} . \mathrm{NC}$ $\mathrm{NC}$, untreated control.

A

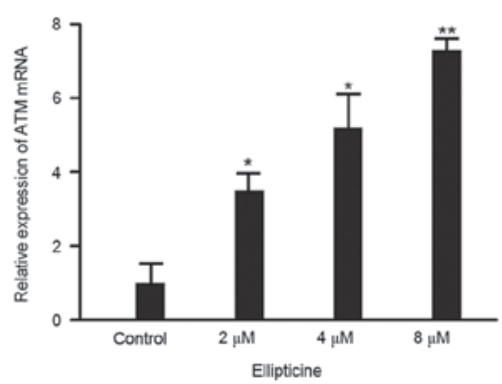

B

Control

P-ATM

p-Cde25C

(Ser-216)

Cdc25C

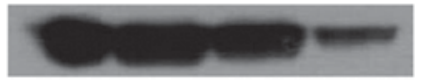

GAPDH
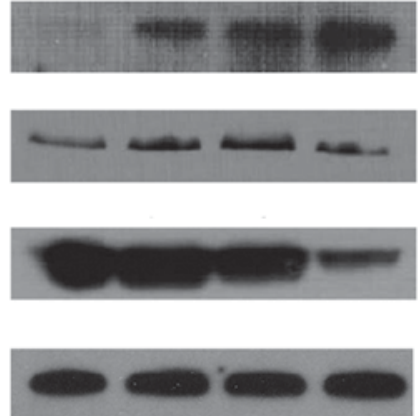

p-Chk1 (Ser-345)
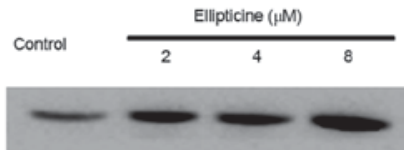

Chk1

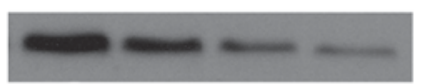

Cycin B1

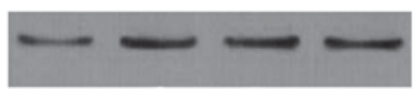

cok1

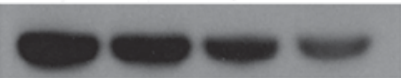

GAPDH

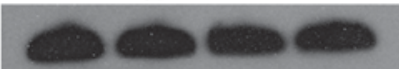

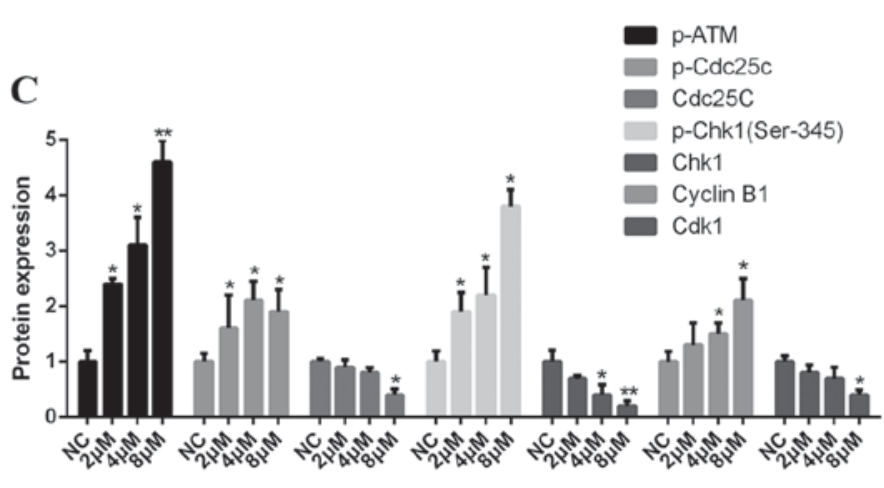

Ellipticine

Figure 4. mRNA and protein expression analysis in T-24 bladder cancer cells treated with various concentrations of ellipticine for 24 h. The data are presented as mean \pm standard deviation. (A) ATM mRNA expression was assessed in untreated (control) and ellipticine-treated cells. Results are plotted as relative expression to the control cells. (B) Western blot analysis of untreated (control) and ellipticine-treated cells. A representative blot is shown from three independent experiments with similar results. (C) Quantification of protein expression from densitometric analysis relative to the GAPDH control from three independent experiments. ${ }^{*} \mathrm{P}<0.05,{ }^{* *} \mathrm{P}<0.01$ vs. untreated control. ATM, ATM serine/threonine kinase; p-, phosphorylated; Cdc25, M-phase inducer phosphatase 3; Chk1, checkpoint kinase 1; Cdk1, cyclin dependent kinase 1.

study hypothesized that ellipticine could significantly inhibit $\mathrm{T}-24$ cell proliferation in a dose- and time- dependent manner.
Previous studies suggested that the mechanism underlying the cytotoxicity of ellipticine is related to covalent binding 
of ellipticine to DNA in neuroblastoma cell lines (14) and the interaction of ellipticine with a human DNA sequence derived from the telomeric DNA region (15). Low concentrations (1-4 $\mu \mathrm{M})$ of ellipticine have been demonstrated to exhibit considerable cytotoxicity, which, combined with its limited intrinsic toxicity (4), suggests that ellipticine could be a promising therapeutic molecule against bladder cancer.

Loss of key cell cycle checkpoints is a hallmark of cancer, inducing abnormal proliferation and subsequent oncogenic transformation (16). Among phosphoinositide kinase (PIK)-related proteins family members, ATM is one of the key kinases responding to DNA damage during cell cycle checkpoints. A series of downstream substrates including Chk1, p53, nijmegen breakage syndrome 1 and p38 mitogen-activated protein kinase are targets of ATM, participating in modulating the cell cycle. Among these substrates, Chk1 is the most conserved during evolution (17). p-ATM leads to self-activation through disjoining ATM dimer into monomer, which further activates Chk1 by phosphorylation of Ser-345 sites, thereby causing deactivation of p-Cdc25C (18). $\mathrm{Cdk} 1$ is a cyclin-dependent kinase, which bonds to cyclin B1, and the complex facilitates dividing cells to enter mitosis from $\mathrm{G} 2$ phase (13). By means of deactivated Cdc25C, Cdk1 cannot be dephosphorylated by $\mathrm{Cdc} 25 \mathrm{C}$, which leads to a deactivated status of Cdk1-cyclinB1 complex (19). In conclusion, activated Chk1 leads to Cdk1 inhibition by deactivation of $\mathrm{Cdc} 25$ through phosphorylation which results in G2-arrest (20). Previous studies have suggested that ellipticine is a potent inhibitor of cell-cycle progression in several different cell lines $(6,21)$. The present study has focused on the effect of ellipticine on the T-24 cell cycle and demonstrated that ellipticine causes a $\mathrm{G} 2 / \mathrm{M}$ phase arrest. Similar results were observed in human endometrial and breast carcinomas $(21,22)$. The present study demonstrated that ellipticine treatment increased the percentage of cells in G2/M phase from 13.75 to $23.75 \%$, in a dose-dependent manner, which suggests that the ellipticine-induced cell growth inhibition is related to cell cycle arrest. The ATM-Chk1-Cdc25C-Cdk1 pathway was examined, which revealed that treatment with ellipticine induces $\mathrm{G} 2 / \mathrm{M}$ arrest via activation of the ATM-Chk1-Cdc25C-Cdk1 pathway. In addition, as demonstrated in Fig. 3, the percentage of cells in S-phase was 33.86, 32.45, 37.56, 40.17, 49.63 and $46.96 \%$ with ellipticine concentrations of $0,1,2,4,8$ and $16 \mu \mathrm{M}$, respectively. Unlike the $\mathrm{G} 2 / \mathrm{M}$ phase, the $\mathrm{S}$-phase revealed a non-dose dependent reduction, therefore suggesting that this was not a specific change caused by ellipticine. Fang et al (8) demonstrated that Akt is also the target of ellipticine in lung cancer. In the present study, ATM was confirmed to be a target of ellipticine in bladder cancer, but further research is needed to test for other targets. In addition, the mechanisms by which the ATM-Chk1-Cdc25C-Cdk1 pathway was activated by ellipticine treatment are not clear and need to be explored further.

To the best of our knowledge, the present study is the first to evaluate the motility of bladder cancer cells following ellipticine treatment in vitro. Using the T-24 bladder cancer cell line, a significant and dose-dependent decrease in motility was demonstrated following ellipticine treatment. Although a single cell line was used to substantiate these findings, T-24 is a typical bladder epithelial cell line which is hypothesized to accurately represent the features of bladder cancer. In preliminary experiments, the proliferation of T-24, 5637, UM-UC-3 and J82 cell lines treated with ellipticine was assessed by CCK-8 assay, which revealed that the inhibitory effect on T-24 cells was the most significant (data not shown). Finally, although an effect of ellipticine in the motility of bladder cancer cells was demonstrated in the present study, the molecular mechanisms underlying this reduction remain unknown and future studies will be required to address this.

In conclusion, the present study demonstrated that ellipticine induces cell death and G2/M cell cycle arrest and diminishes the migration ability of T-24 bladder cancer cells in a dose- and time-dependent manner. As demonstrated by western blot analysis of the ATM-Chk1-Cdc25C-Cdk1 pathway, ellipticine may inhibit cellular proliferation by generating a cell cycle arrest at the $\mathrm{G} 2 / \mathrm{M}$ phase in $\mathrm{T}-24$ bladder cancer cells via the ATM pathway. Further investigation of the molecular events underlying ellipticine-triggered cancer cell inhibition is required to fully assess the potential of ellipticine as a therapeutic in bladder cancer.

\section{References}

1. Goodwin S, Smith AF and Horning EC: Alkaloids of ochrosia elliptica labill. J Am Chem Soc 81: 1903-1908, 1959.

2. Rouësse JG, Le Chevalier T, Caille P, Mondesir JM, Sancho-Garnier H, May-Levin F, Spielmann M, De Jager R and Amiel JL: Phase II study of elliptinium in advanced breast cancer. Cancer Treat Rep 69: 707-708, 1985.

3. Stiborová M, Bieler CA, Wiessler M and Frei E: The anticancer agent ellipticine on activation by cytochrome P450 forms covalent DNA adducts. Biochem Pharmacol 62: 1675-1684, 2001.

4. Auclair C: Multimodal action of antitumor agents on DNA: The ellipticine series. Arch Biochem Biophys 259: 1-14, 1987.

5. Martinkova E, Maglott A, Leger DY, Bonnet D, Stiborova M, Takeda K, Martin S and Dontenwill M: alpha5beta1 integrin antagonists reduce chemotherapy-induced premature senescence and facilitate apoptosis in human glioblastoma cells. Int $\mathrm{J}$ Cancer 127: 1240-1248, 2010.

6. Kuo PL, Hsu YL, Kuo YC, Chang $\mathrm{CH}$ and Lin CC: The anti-proliferative inhibition of ellipticine in human breast mda-mb-231 cancer cells is through cell cycle arrest and apoptosis induction. Anticancer Drugs 16: 789-795, 2005.

7. Kuo YC, Kuo PL, Hsu YL, Cho CY and Lin CC: Ellipticine induces apoptosis through p53-dependent pathway in human hepatocellular carcinoma HepG2 cells. Life Sci 78: 2550-2557, 2006.

8. Fang K, Chen SP, Lin CW, Cheng WC and Huang HT: Ellipticine-induced apoptosis depends on Akt translocation and signaling in lung epithelial cancer cells. Lung Cancer 63: 227-234, 2009.

9. Chavan S, Bray F, Lortet-Tieulent J, Goodman M and Jemal A: International variations in bladder cancer incidence and mortality. Eur Urol 66: 59-73, 2014.

10. Amsellem-Ouazana D, Bièche I, Tozlu S, Botto H, Debre B and Lidereau R: Gene expression profiling of ERBB receptors and ligands in human transitional cell carcinoma of the bladder. J Urol 175: 1127-1132, 2006.

11. Pliarchopoulou K, Laschos K and Pectasides D: Current chemotherapeutic options for the treatment of advanced bladder cancer: A review. Urol Oncol 31: 294-302, 2013.

12. Livak KJ and Schmittgen TD: Analysis of relative gene expression data using real-time quantitative PCR and the 2(-Delta Delta C(T)) Method. Methods 25: 402-408, 2001.

13. Peng CY, Graves PR, Thoma RS, Wu Z, Shaw AS and Piwnica-Worms H: Mitotic and G2 checkpoint control: Regulation of 14-3-3 protein binding by phosphorylation of Cdc25C on serine-216. Science 277: 1501-1505, 1997.

14. Stiborova M, Poljakova J, Eckschlager T, Kizek R and Frei E: Analysis of covalent ellipticine- and doxorubicin-derived adducts in DNA of neuroblastoma cells by the ${ }^{32} \mathrm{P}$-postlabeling technique. Biomed Pap Med Fac Univ Palacky Olomouc Czech Repub 156: 115-121, 2012. 
15. Ghosh S, Kar A, Chowdhury S and Dasgupta D: Ellipticine binds to a human telomere sequence: An additional mode of action as a putative anticancer agent? Biochemistry 52: 4127-4137, 2013.

16. Zhou BB and Elledge SJ: The DNA damage response: Putting checkpoints in perspective. Nature 408: 433-439, 2000

17. Helt CE, Cliby WA, Keng PC, Bambara RA and O'Reilly MA: Ataxia telangiectasia mutated (ATM) and ATM and Rad3-related protein exhibit selective target specificities in response to different forms of DNA damage. J Biol Chem 280: 1186-1192, 2005.

18. Thanasoula M, Escandell JM, Suwaki N and Tarsounas $\mathrm{M}$ : ATM/ATR checkpoint activation downregulates CDC25C to prevent mitotic entry with uncapped telomeres. EMBO J 31: 3398-3410, 2012.
19. Graves PR, Lovly CM, Uy GL and Piwnica-Worms H: Localization of human Cdc $25 \mathrm{C}$ is regulated both by nuclear export and 14-3-3 protein binding. Oncogene 20: 1839-1851, 2001.

20. Taylor WR and Stark GR: Regulation of the G2/M transition by p53. Oncogene 20: 1803-1815, 2001.

21. Kim JY, Lee SG, Chung JY, Kim YJ, Park JE, Koh H, Han MS, Park YC, Yoo YH and Kim JM: Ellipticine induces apoptosis in human endometrial cancer cells: The potential involvement of reactive oxygen species and mitogen-activated protein kinases. Toxicology 289: 91-102, 2011.

22. Kuo PL, Hsu YL, Chang CH and Lin CC: The mechanism of ellipticine-induced apoptosis and cell cycle arrest in human breast MCF-7 cancer cells. Cancer Lett 223: 293-301, 2005. 